------Jou. Raf. Sci., Vol. 20, No.4 pp 69- 81, 2009------

\title{
Spectrophotometric Determination of Phenylephrine Hydrochloride by Coupling with Diazotized 2- Aminobenzothiazole
}

\author{
Nabeel S. Othman Noha Th. Abdul Fatah \\ Department of Chemistry \\ College of Science \\ Mosul University
}

(Received 17 / 6 / 2009 ; Accepted 5 / 10 / 2009)

\begin{abstract}
A spectrophotometric method for determination of microgram amounts of phenylephrine- $\mathrm{HCl}(\mathrm{PE})$ has been proposed. The method is based on coupling of phenylephrine- $\mathrm{HCl}$ with diazotized 2-aminobenzothiazole in alkaline medium. The molar absorptivity of the formed dye is $6.620 \times 10^{3} 1 . \mathrm{mol}^{-1} . \mathrm{cm}^{-1}$ at $\lambda$ max $510 \mathrm{~nm}$ and Beers law obeyed within in the range of $10-250 \mu \mathrm{g}$ of phenylephrine- $\mathrm{HCl} / 25 \mathrm{ml}(0.4-10 \mathrm{ppm})$. The colour reaction was highly stable and did not show a significant change in absorbance(within acceptable analytical error) up to $48 \mathrm{~h}$ with a relative error +0.31 to $+1.07 \%$ and a relative standard deviation of \pm 0.95 to $\pm 3.09 \%$, depending on concentration level. The method has been applied successfully to the determination of phenylephrine-HCl in pharmaceutical preparation (nose drop) .
\end{abstract}

Keywords: phenylephrine;2-aminobenzothiazole;diazo-coupling; spectrophotometry

\section{التقدير الطيفي للقنيل افرين هيدروكلور ايد بالاقتران مع العامل المؤزوت 2 -امينوينزوثايزول}

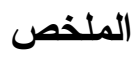

تم اقتز اح طريقة طيفيه لتقدير كميات متتاهية في الصغر من الفنيل افرين هيدروكلوريد. تعتمد

الطريقة على الاقتران مع العامل المؤزوت 2 -امينوبنزوثايزول في الوسط القاعدي. بلغت قيمة معامل

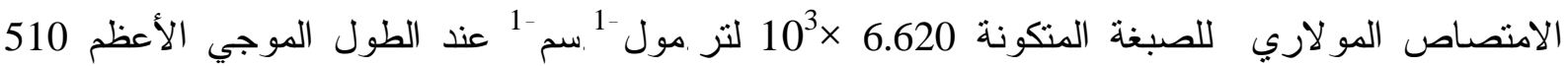
نانوميتر بوتتبع الطريقه قانون بير في مدى التراكيز من 10 - 250 مايكروغرام/ 25 مل(0.4 - 10 جزء/مليون). يمتاز التفاعل اللوني باستقرارية عالية ولا يوجد تغيير ملحوظ في الامتصاصية (ضمن الخطأ المسموح) لددة لاتقل عن 48 ساعة وبخطأ نسبي بتراوح بين 0.31 و 1.07\% و انحر اف قباسي نسبي بين 0.95 و 3.09 ٪ \% اعتمادا على مستوى التركيز. تم تطبيق الطريقة بنجاح في تقدير الفنيل افرين هيدروكلوريد في مستحضره الصيدلاني(قطرة الأنف) . 


\section{INTRODUCTION}

Phenylephrine hydrochloride[3-(hydroxylphenyl)-2-(methylamino)ethanol] ydrochloride is widely used as a decongestant drug (Al-Abachi and Al-Ward, 2002). The drug is available as an oral medicine or as a nasal spray. Phenylephrine is rarely used as a vasopressor due to its increase in the blood pressure for unstable patients with hypotension. (Louis, 1985) .

Different spectrophotometric methods have been applied for the determination of phenylephrine with different reagents such as 4-aminoantipyrine in presence of periodate or alkaline ferricyanide (Al-Abachi and Al-Ward, 2002; Hiskey and Levin, 1960), nitrous acid in presence of copper ion (Yahia and Laila, 1976), chloranil (Amer et al., 1982), ninhydrin in sulphuric acid (Muszalska et al., 2000), periodate (Neil and Gelenn, 1971), methylbenzothiazoline-2-one hydrazone in presence of iron (Gala et al., 1994), haematoxylin (Ibrahim;Alaa,2007), 4-aminophenol (Sane and Narkar,1980), chloramine (Szekerer et al., 1973), N,N-dimethylaniline hydrochloride with potassium ferricyanide (Tatsuzawa and Shimoda, 1968), hydroxyl ammonium chloride with cupric ion (Deodhar and Mehta, 1978), sodium borate (Doulakas, 1975), fluorodinitrobenzene (Tammilehto, 1975), bromothymol blue (Matthew et al.,1972), and diazotized p-nitroaniline (Auerbach, 1950; Kelly and Auerbach, 2006). Also, the ultraviolet (Fabrizo, 2006) and derivative spectrophotometry (Kazemipour and Ansari, 2005) methods have been used.

The flow injection methods have been used in the determination of phenylephrine with spectrophotometric detection (Yolanda et al., 2001; Knochen and Giglio, 2004; Beyene and Vanstaden, 2004).

Also, the high performance liquid chromatography technique has been applied to the determination of trace amounts of phenylephrine (Amer et al., 2008; Marin and Barbas, 2004, Senyuva and Ozden, 2002).

The objective of investigation reported in this paper is to evaluate a sensitive and an accurate method for the assay of phenylephrine in an aqueous medium, either in pure form or in its pharmaceutical preparations. The method based on coupling of phenylephrine with diazotized 2-aminobenzothiazol in alkaline medium to produce an intense azo dye which was considered desirable to develop an additional assay method suitable for accurate and reliable quality control of phenylephrine formulations.

\section{Apparatus}

\section{EXPERIMENTAL}

Shimadzu UV-Visible Recording Spectrophotometer UV-160 with $1.0 \mathrm{~cm}$ matched silica cells was used for all absorption measurements.

\section{Reagent}

All Chemicals used were of analytical-reagent grade .

A pure phenylephrine - $\mathrm{HCl}$ ( $\mathrm{PE}$ ) was obtained from the State company for Drug Industries and Medical Applicances(SDI), Sammara, Iraq. A solution of $100 \mu \mathrm{g} \mathrm{ml}^{-1}$ was prepared by dissolving $0.01 \mathrm{~g}$ of phenylephrine- $\mathrm{HCl}$ in $100 \mathrm{ml}$ distilled water. Sodium hydroxide $(2 \mathrm{~N})$ and different interferences solution $\left(1000 \mu \mathrm{g} \mathrm{m}{ }^{-1}\right)$ were prepared by dissolving the proper amount in distilled water.

The diazotized 2-aminobenzothiazole $(25 \mathrm{mM})$ solution was daily prepared by dissolving $0.1877 \mathrm{~g}$ of 2 -aminobenzothiazole (Fluka) in $10 \mathrm{ml}$ ethanol and $5 \mathrm{ml}$ of concentrated sulphuric acid (Samir and Uma, 2005), followed by the addition of about $25 \mathrm{ml}$ distilled 
water. Finally the mixture was transferred to a $50 \mathrm{ml}$ volumetric flask and is cooled at 0-5 ${ }^{\mathrm{O}} \mathrm{C}$ in an ice-bath. A $0.0862 \mathrm{~g}$ sodium nitrite was added and the mixture was stirred vigorously. After 5 minutes, the solution was made up to $50 \mathrm{ml}$ with cold distilled water. The solution was kept in a brown bottle in a refrigerator for 1 hour before using.

\section{General procedure and calibration graph}

The aqueous solution $(0.1-3 \mathrm{ml})$ contain phenylephrine- $\mathrm{HCl}\left(100 \mu \mathrm{g} . \mathrm{ml}^{-1}\right)$ was transferred to $25 \mathrm{ml}$ calibrated flasks.A $2.5 \mathrm{ml}$ of 2-aminobenzothiazole diazotized solution $(25 \mathrm{mM})$, and $4 \mathrm{ml}$ of sodium hydroxide solution $(2 \mathrm{~N})$ were added and the volume was made up to the mark with distilled water. The absorbance was measured at $510 \mathrm{~nm}$ against a blank solution which was prepared in a similar way but without the addition of phenylephrine- $\mathrm{HCl}$.

The calibration graph as shown in Fig. (1) was linear over the range of $10-250 \mu \mathrm{g}$ of phenylephrine- $\mathrm{HCl} / 25 \mathrm{ml}(0.4-10 \mathrm{ppm})$. Higher concentrations show a negative deviation from Beers law. The apparent molar absorptivity referred to phenylephrine $-\mathrm{HCl}$ has been found to be $6.620 \times 10^{3} 1 . \mathrm{mol}^{-1} \cdot \mathrm{cm}^{-1}$.

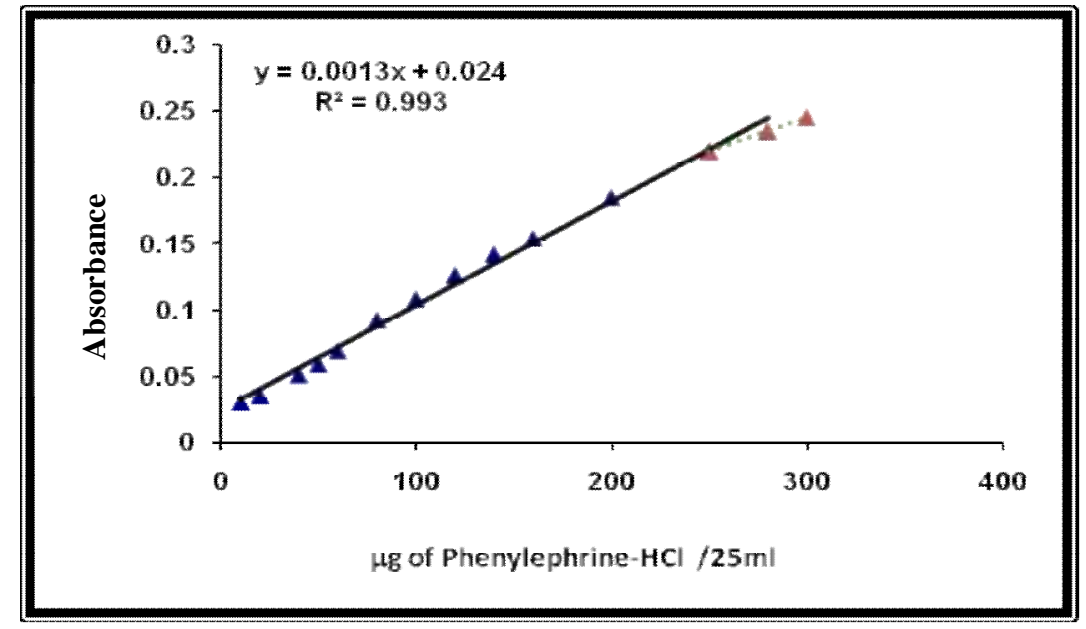

Fig. 1: Calibration graph for phenylephrine $-\mathrm{HCl}$ determination using the proposed method

\section{Procedure for the phenylephrine-HCl nose drop}

The contents of three of phenylephrine $-\mathrm{HCl}$ nose drop containers (nasal drop, SDI, Sammara, Iraq) were mixed. An accurate volume containing $0.005 \mathrm{mg}$ phenylephrine $\mathrm{HCl}$ was transferred to a $50 \mathrm{ml}$ volumetric flask, and the volume adjusted to the mark with distilled water and, then it was proceeded as described under procedure for calibration.

\section{RESULTS AND DISCUSSION}

The effect of various variables on the colour development was tested to establish the optimum conditions for determination of PE by coupling with diazotized 2aminobenzothiazole reagent. 


\section{PRINCIPLE OF THE METHOD}

The method involves the coupling of phenylephrine drug with diazotized 2aminobenzothiazole in basic medium to form an intensely - coloured azo dye:-<smiles>CNCC(O)c1cccc(O)c1</smiles>

Diazotised 2-aminobenzothiazole

\section{Choice of diazotised agent}

Several aromatic diazotised agents have been tested for optimum conditions. The results in Table 1 show that 2 -aminobenzothiazole give the most sensitive reaction $(\varepsilon=$ $\left.8.810 \times 10^{3} 1 . \mathrm{mol}^{-1} . \mathrm{cm}^{-1}\right)$ in alkaline medium. Therefore, it has been selected for subsequent experiments.

Table 1: The selection of diazotized agent

\begin{tabular}{|c|c|c|c|}
\hline $\begin{array}{l}\text { Reagent } \\
(0.025 M)\end{array}$ & Structure & $\Delta \lambda . \mathbf{n m}$ & $\varepsilon\left(\mathbf{l} \mathrm{mol}^{-1} \cdot \mathrm{cm}^{-1}\right)$ \\
\hline $\begin{array}{c}\text { 4-aminosalicylic } \\
\text { acid }\end{array}$ & & & No colour contrast \\
\hline Benzocaine & & 60 & $8.606 \times 10^{3}$ \\
\hline 2-aminobenzothiazole & & 213 & $8.810 \times 10^{3}$ \\
\hline p-aminobenzoic acid & & 64 & $6.264 \times 10^{3}$ \\
\hline Sulphanilic acid & & 43 & $7.435 \times 10^{3}$ \\
\hline 2-aminobenzophenone & & 63 & $5.092 \times 10^{3}$ \\
\hline
\end{tabular}

$* \Delta \lambda=$ Colour contrast $=\lambda \max S-\lambda \operatorname{maxB}$

where $\mathrm{S}=$ The dye, $\mathrm{B}=\mathrm{Blank}$ 


\section{Effect of diazotized 2-aminobenzothiazole reagent amount}

The effect of different amounts of diazotized 2-aminobenzothiazole reagent on the absorbance of solutions containing different amounts of phenylephrine- $\mathrm{HCl}(20-200 \tilde{}$. $\mu \mathrm{g} / 25$ $\mathrm{ml}$ ) was studied. The obtained results indicated that the absorbance increases with increasing reagent concentration and reached a maximum on using a volume of $2.5 \mathrm{ml}$ of $25 \mathrm{mM}$ diazotized 2-aminobenzothiazole which also gives the highest value of coefficient of determination $\left(\mathrm{r}^{2}\right)$ (Table2). Therefore, the addition of $2.5 \mathrm{ml}$ reagent was recommended for the subsequent experiments.

Table 2:The effect of the amount of diazotized 2- aminobenzothiazole on dye absorbance

\begin{tabular}{|c|c|c|c|c|c|c|c|}
\hline \multirow{2}{*}{$\begin{array}{c}\text { ml of } \\
2- \\
\text { Aminobenzothiazole } \\
\text { solution } 25 \mathrm{mM}\end{array}$} & \multicolumn{6}{|c|}{ Absorbance / $\mu \mathrm{g}$ of phenylephrine-HCl in $25 \mathrm{ml}$} & \multirow{2}{*}{$\mathbf{r}^{2}$} \\
\hline & 20 & 50 & 80 & 100 & 150 & 200 & \\
\hline 1 & 0.025 & 0.030 & 0.040 & 0.045 & 0.074 & 0.075 & 0.93698 \\
\hline 2 & 0.029 & 0.036 & 0.053 & 0.065 & 0.089 & 0.115 & 0.9935 \\
\hline 2.5 & 0.029 & 0.058 & 0.090 & 0.103 & 0.134 & 0.170 & 0.9973 \\
\hline 3 & 0.034 & 0.041 & 0.073 & 0.099 & 0.118 & 0.167 & 0.9749 \\
\hline
\end{tabular}

\section{Effect of base}

Preliminary experiments have shown that PE gives coloured dye with diazotized 2aminobenzothiazole only in basic medium. Different bases (strong and weak) have been used and the results (Table 3 ) indicate that the formation of the coloured dye needs a strong basic medium. Therefore $4 \mathrm{ml}$ of $2 \mathrm{~N} \mathrm{NaOH}$ solution has been recommended for the subsequent experiments. 
Nabeel S. Othman and Noha Th. Abdul Fatah

Table 3: The effect of base on dye absorbance

\begin{tabular}{|c|c|c|c|c|c|c|}
\hline \multirow{2}{*}{$\begin{array}{c}\text { Base used } \\
(2 \mathrm{~N}) \\
\text { solution }\end{array}$} & \multirow{2}{*}{ Variable } & \multicolumn{4}{|c|}{ Absorbance* / ml of base used } & \multirow{2}{*}{ pH range } \\
\hline & & 3 & 4 & 6 & 8 & \\
\hline \multirow[t]{2}{*}{$\mathrm{NaOH}$} & A & 0.054 & 0.113 & 0.101 & 0.105 & \multirow{2}{*}{$2.36-13.32$} \\
\hline & $\Delta \lambda^{* *}, \mathrm{~nm}$ & 139 & 232 & 233 & 230 & \\
\hline \multirow{2}{*}{$\mathrm{KOH}$} & A & 0.045 & 0.052 & 0.086 & 0.088 & \multirow{2}{*}{$2.34-13.65$} \\
\hline & $\Delta \lambda, \mathrm{nm}$ & 139 & 137 & 228 & 226 & \\
\hline \multirow{2}{*}{$\mathrm{Na}_{2} \mathrm{CO}_{3}$} & A & 0.030 & 0.029 & 0.026 & 0.029 & \multirow{2}{*}{$1.82-9.70$} \\
\hline & $\Delta \lambda, \mathrm{nm}$ & 62 & 63 & 61 & 61 & \\
\hline \multirow{2}{*}{$\mathrm{NaHCO}_{3}$} & A & 0.001 & 0.022 & 0.170 & 0.191 & \multirow{2}{*}{$1.36-7.10$} \\
\hline & $\Delta \lambda, \mathrm{nm}$ & 136 & 129 & 78 & 58 & \\
\hline
\end{tabular}

\section{Effect of surfactant}

The effect of several types of surfactants on colour intensity of the dye has been investigated.The results indicate that addition of surfactants give no useful effect [increasing the intensity or improving the colour contrast $(\Delta \lambda)$ ], therefore it has not been used in the subsequent experiments.

\section{Order of addition of reagents}

The order of additions of reagents [phenylephrine- $\mathrm{HCl}(\mathrm{PE}), \mathrm{NaOH}(\mathrm{OH}), 2$ -

aminobenzothiazole (R)] was examined. The results (shown in Table 4) indicated that order

(I) of addition of reagents was the optimum order due to the high intensity of the formed azo dye.

Table 4: Effect of order of addition

\begin{tabular}{|c|c|c|}
\hline Reaction component & Order number & Absorbance \\
\hline $\mathrm{PE}+\mathrm{R}+\mathrm{OH}$ & $\mathrm{I}$ & 0.109 \\
\hline $\mathrm{OH}+\mathrm{PE}+\mathrm{R}$ & $\mathrm{II}$ & 0.075 \\
\hline $\mathrm{OH}+\mathrm{R}+\mathrm{PE}$ & III & 0.014 \\
\hline
\end{tabular}




\section{Effect of time and amount of PE on absorbance}

The effect of time on the development and stability period of the formed coloured dye was investigated under optimum experimental conditions described before. The formation of coloured dye being complete after mixing the component of reaction and the absorbance of the coloured species remained constant for, at least 48 hours (Table5).

Table 5: The effect of time on absorbance

\begin{tabular}{|c|c|c|c|}
\hline \multirow{2}{*}{ Time/min. } & \multicolumn{3}{|c|}{ Absorbance/ $\boldsymbol{\mu g}$ of phenylephrine-HCl } \\
\cline { 2 - 4 } & 100 & 200 & 260 \\
\hline 0 & 0.085 & 0.172 & 0.301 \\
\hline 5 & 0.084 & 0.171 & 0.301 \\
\hline 10 & 0.084 & 0.171 & 0.301 \\
\hline 20 & 0.083 & 0.171 & 0.301 \\
\hline 30 & 0.084 & 0.172 & 0.301 \\
\hline 40 & 0.084 & 0.172 & 0.301 \\
\hline 50 & 0.084 & 0.172 & 0.301 \\
\hline 60 & 0.084 & 0.172 & 0.301 \\
\hline 120 & 0.089 & 0.172 & 0.300 \\
\hline $18 \mathrm{~h}$ & 0.085 & 0.171 & 0.299 \\
\hline $24 \mathrm{~h}$ & 0.086 & 0.170 & 0.292 \\
\hline $48 \mathrm{~h}$ & 0.082 & 0.166 & 0.290 \\
\hline $72 \mathrm{~h}$ & 0.080 & 0.162 & 0.284 \\
\hline $96 \mathrm{~h}$ & 0.079 & 0.162 & 0.292 \\
\hline
\end{tabular}

\section{Final absorption spectra}

An absorption spectra of the formed coloured dye by coupling of PE with diazotized 2-aminobenzothiazole in basic medium, against its corresponding reagent blank show a maximum absorption at $510 \mathrm{~nm}$ in contrast to the reagent blank ( Fig 2). 


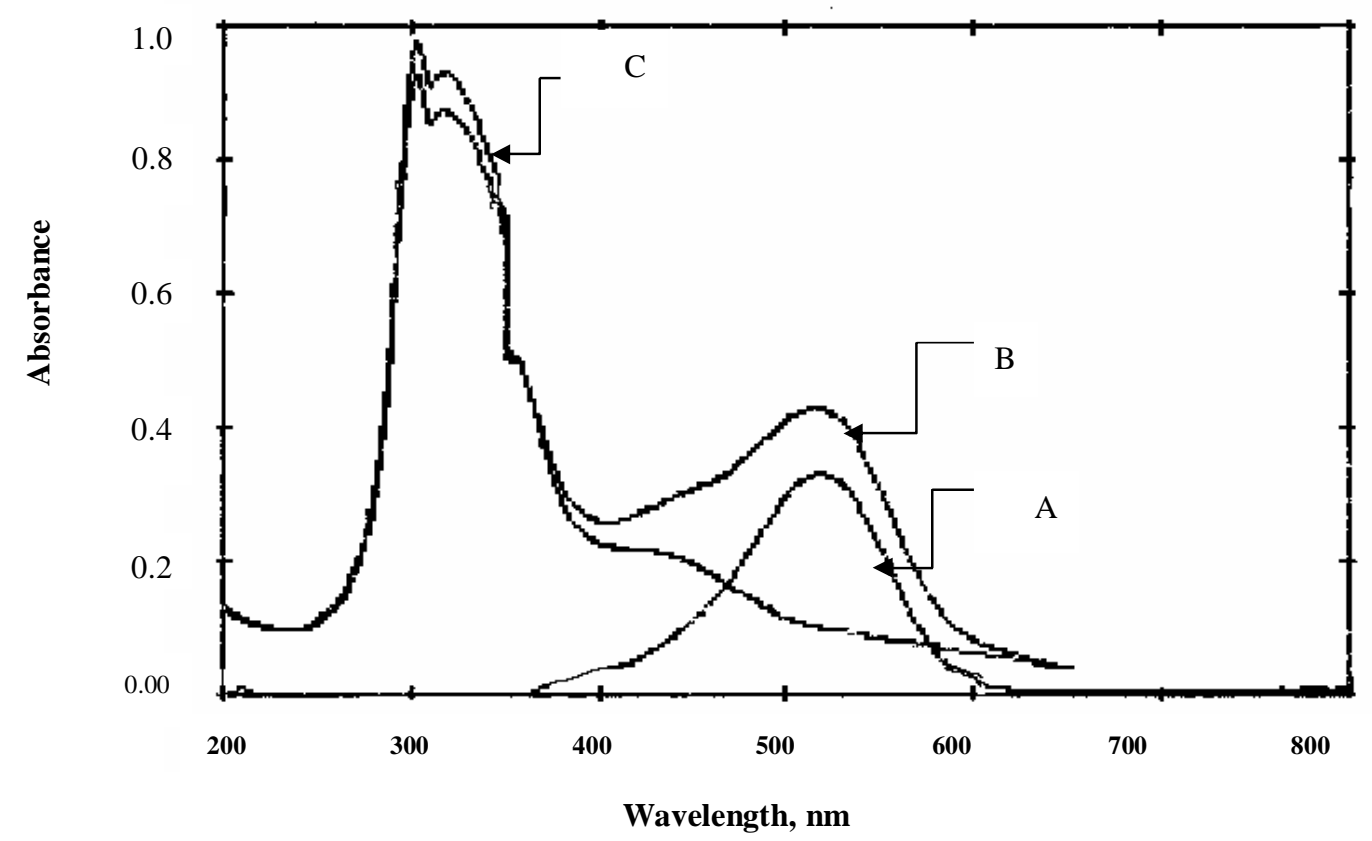

Fig. 2: Absorption spectra of $250 \mu \mathrm{g}$ PE treated according to the recommended procedure and measured against (A) blank (B) distilled water and (C) blank measured against distilled water.

\section{Interference}

The criterion of interference was an error of not more than $\pm 5.0 \%$ in the absorbance. To test the efficiency and selectivity of the proposed analytical method, a systematic study of excipients (e.g., glucose, lactose, gum Arabic and starch) that usually present in dosage forms was performed. Experimental results showed that there was no interference from additives or excipients up to $1000 \mu \mathrm{g}$ in the present method as shown in Table 6 .

Table 6 : Effect of foreign compounds for assay of phenylephrine- $\mathrm{HCl}$

\begin{tabular}{|c|c|c|c|}
\hline \multirow{2}{*}{$\begin{array}{c}\text { Foreign } \\
\text { compound }\end{array}$} & \multicolumn{3}{|c|}{$\begin{array}{c}\text { Recovery (\%) of 100 } \boldsymbol{\mu g} \text { phenylephrine-HCl per } \boldsymbol{\mu g} \\
\text { foreign compound added }\end{array}$} \\
\cline { 2 - 4 } Glucose & $\mathbf{1 0 0}$ & $\mathbf{5 0 0}$ & $\mathbf{1 0 0 0}$ \\
\hline Gum Arabic & 101.6 & 100.8 & 103.3 \\
\hline Lactose & 107.1 & 105 & 96.6 \\
\hline Starch & 105.8 & 103.3 & 97.50 \\
\hline
\end{tabular}




\section{Accuracy and precision}

To check the accuracy and precision of the calibration curve, PE was determined at three different concentrations. The results (illustrated in Table 7) indicate that the method is satisfactory.

Table 7. Accuracy and precision of the calibration curve

\begin{tabular}{|c|c|c|}
\hline $\begin{array}{c}\text { Amount of } \\
\text { phenylephrine-HCl } \\
\text { taken, } \boldsymbol{\mu g}\end{array}$ & Relative error, \%* & $\begin{array}{c}\text { Relative standard } \\
\text { deviation, \%* }\end{array}$ \\
\hline 80 & +1.07 & \pm 3.09 \\
\hline 160 & +0.74 & \pm 1.21 \\
\hline 260 & +0.32 & \pm 0.95 \\
\hline
\end{tabular}

*Average of four determinations

\section{Nature of the Dye}

Job's and mole - ratio methods (Hargis, 1988) indicate that the azo dye has a composition of 1:2 phenylephrine [PE] to diazotized 2-aminobenzothiazole [AM]reagent (Fig.3 and 4) .

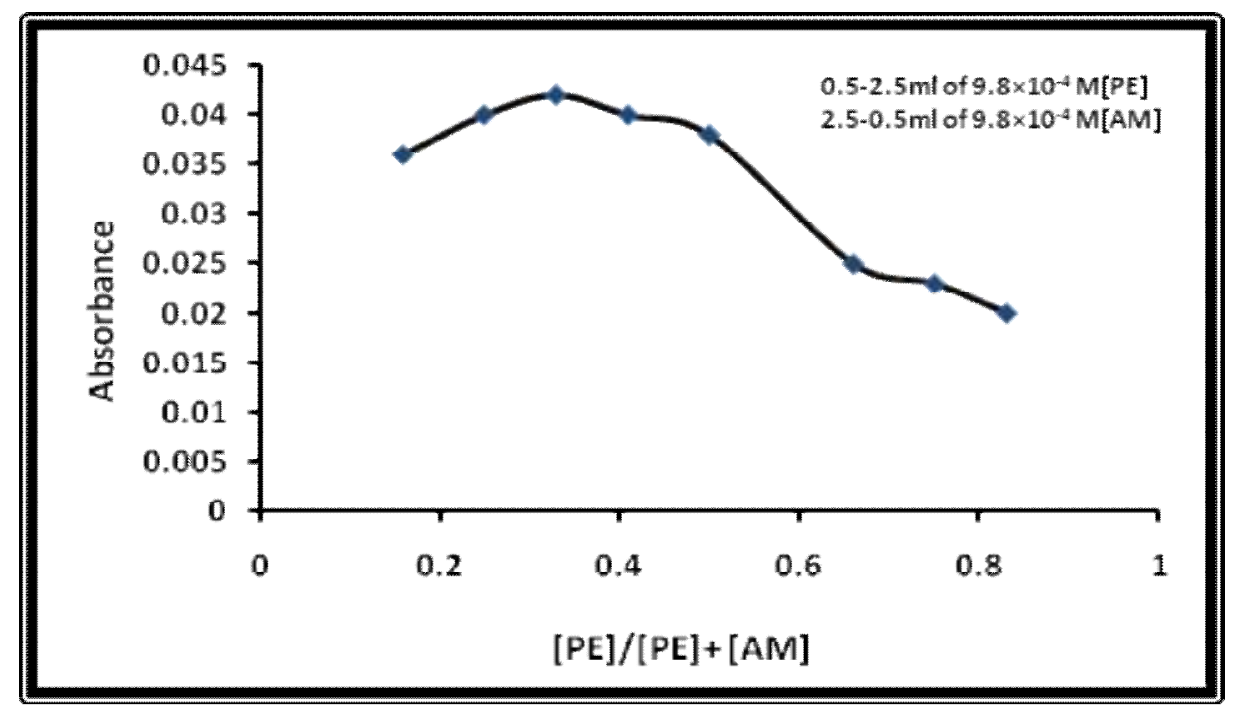

Fig.3: Job's plot for phenylephrine - diazotized 2-aminobenzothiazole 


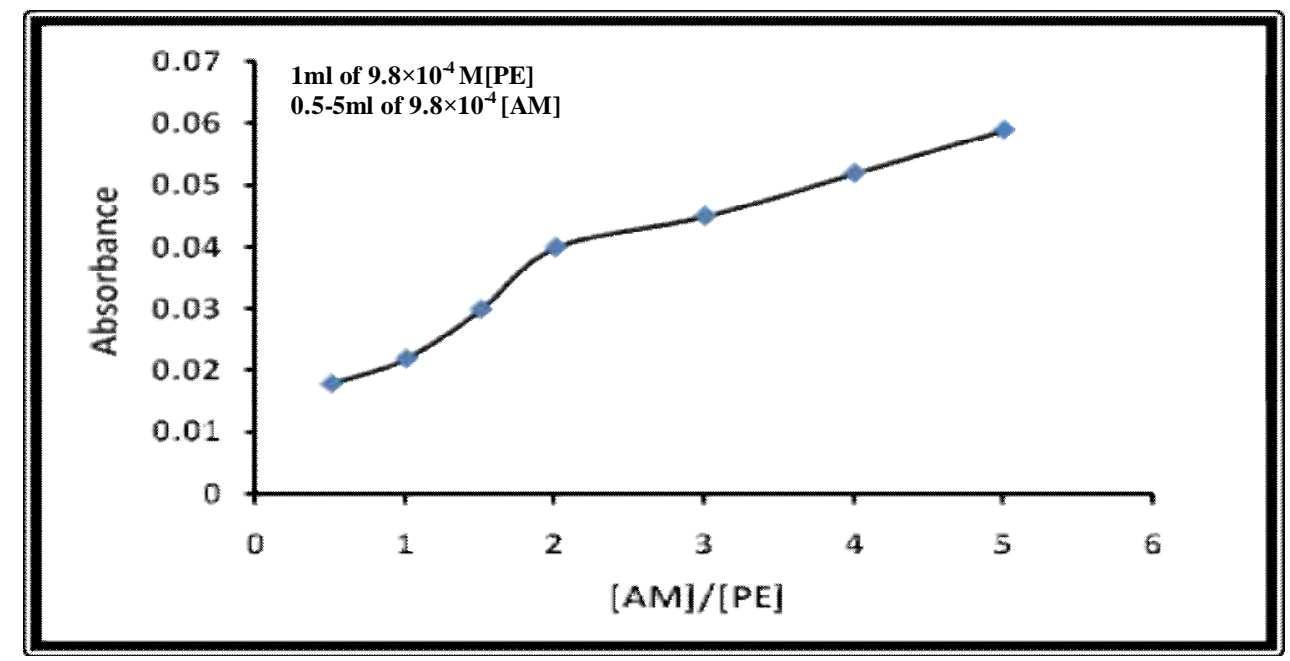

Fig.4: Mole ratio plot for- phenylephrine - diazotized 2-aminobenzothiazole

Hence, the dye may have the following structure.<smiles>CNCC(O)c1cc(O)c(N=Nc2nc3ccccc3s2)cc1N=Nc1nc2ccccc2s1</smiles>

\section{Orange-red azo dye}

\section{Application of the Method}

The proposed method was successfully applied to determine phenylephrine in its pharmaceutical prepration(nose drop)(Table 8). The performance of the proposed method was assessed by calculation of the t-test compared with the standard method(British Pharmacopeia,2000) (potentiometric titration with sodium hydroxide ) for $95 \%$ confidence level with four degrees of freedom. The results showed that the t-value was less than the critical value, indicated that there was no significant difference between the proposed and standard method for phenylephrine. 
Table 8: Analytical applications of the proposed method and expremental t-value

\begin{tabular}{|c|c|c|c|c|}
\hline $\begin{array}{c}\text { Pharmaceutical } \\
\text { preparation }\end{array}$ & $\begin{array}{c}\boldsymbol{\mu g} \\
\text { Phenylephrine- } \\
\text { HCl present }\end{array}$ & $\begin{array}{c}\text { Recovery \% } \\
\text { by the } \\
\text { present } \\
\text { method }\end{array}$ & $\begin{array}{c}\text { Recovery \% } \\
\text { by the } \\
\text { standard } \\
\text { method }\end{array}$ & t-value \\
\hline $\begin{array}{c}\text { Nasophrine } \\
\text { Nasal } \\
\text { Drop(0.25\%) } \\
\text { SDI - Iraq }\end{array}$ & 200 & 103 & 99.6 & 1.21 \\
\hline
\end{tabular}

\section{Comparison of the methods}

Table(9) shows the comparison between some of analytical variables for the present method with that of another literature spectrophotometric method.

Table 9: comparison of the methods

\begin{tabular}{|c|c|c|}
\hline Analytical parameters & Present method & Literature method* \\
\hline pH & 12.97 & \\
\hline Temperature $\left({ }^{\circ} \mathrm{C}\right)$ & Room temperature & Room temperature \\
\hline$\lambda_{\max }(\mathbf{n m})$ & 510 & 500 \\
\hline Reagent & 2-aminobenzothiazole & 4-aminoantipyrine \\
\hline Beer's law range (ppm) & $0.4-11.2$ & $1-36$ \\
\hline$\stackrel{\varepsilon}{e}$ l.mol $\left.^{-1} . \mathrm{cm}^{-1}\right)$ & $0.662 \times 10^{4}$ & $1.26 \times 10^{4}$ \\
\hline Stability(hrs.) & 48 & $1: 30$ \\
\hline $\begin{array}{c}\text { Application of the } \\
\text { method }\end{array}$ & Nose drop & Nose drop \\
\hline
\end{tabular}

* Al-Abachi, M. Q. and Al-Ward, H. S. National J. Chem., 2002, ㅁ, 221.

The results indicate that the proposed method is less sensitive than the literature method but the colour is much more stable.

\section{CONCLUSION}

The proposed method was a simple and has a good sensitivity. The proposed method has advantageous over some of the reported visible spectrophotometric methods with respect to, reproducibility, precision, accuracy and stability of the coloured species. The proposed method is suitable for the determination of phenylephrine in pure form and in nose drop-formulation without excipients interference . 


\section{REFERENCES}

Al-Abachi, M. Q. ; Al-Ward, H. S. (2002). Spectrophotometric micro determination of phenylephrine hydrochloride in pharmaceutical preparations via oxidative coupling with 4-aminoantipyrine in the presence of sodium periodate. National J. Chem., 6 , 221-230.

Amer , M. M. ; Taha , A. M. ; El-Shabouri , S. R. ; Khashaba , P.Y.(1982). Spectrophotometric determination of ephedrine hydrochloride and phenylephrine hydrochloride. J. Ass. off. Anal. Chem., 65,894-898.

Amer , S. M.; Abbas, S. S. ; Shehata, M. A. ; Ali, N. M. (2008). Simultaneous determination of phenylephrine hydrochloride, guaifenesine and chlopheiramine maleate in cough syrup by gradient liquid chromatography. J. AOAC, Int., 91(2), $276-284$.

Auerbach, M. E. (1950). Colorimetric determination of phenylephrine (neo synephrine) in pharmaceutical preparations. J. Am. Pharm. Assoc. 50 (2) , 39, 50-52; Anal. Abstr., (1950), 32, 10d,.

Beyene, N. W. ; Vanstaden, J. F. (2004). Sequential injection spectrophotometric determination of phenylephrine hydrochloride pharmaceutical preparations, Talanta, 63(3), 599.

" British Pharmacopeia on CD-ROM ", (2000). 3rd edn., System simulation Ltd, the stationary office, London .

Deodhar, R. D. ; Mehta, R. C. (1978). Colorimetric estimation of phenylephrine hydrochloride in pharmaceutical formulation. Indian J. Pharm. Sci. , 40(5), 167169; Anal. Abstr., (1979), 37 , 1E56 .

Doulakas, (1975). Rapid spectrophotometric determination of phenylephrine hydrochloride in eye drops in presence of other drugs. J. Pharm. Acta Helv. 50(3), 66-68 ; Anal. Abstr., (1975), 29,4E44.

Fabrizio, F. D. (2006). Spectrophotometric determination of acetaminophen, phenylephrine hydrochloride, codein phosphate and pyrilamine maleate in tablets or powde . J. Pharm. Sci. , 57(4) , 644-645.

Gala , B. ; Gomez-Hens, A. ; Perez-Bendito , D.(1994). Individual and simultaneous determination of ephedrine hydrochloride and phenylephrine hydrochloride by use kinetic methodology. J. Anal. Chem., 349(12),824-828.

Hargis, L.G. (1988). “Analytical Chemistry, Principles and Techniques”, Prentice-Hall Inc, New Jersey. pp. 424- 427.

Hiskey, C. F. ; Levin, N. (1960) . Colorimetric determination of phenylephrine using 4- aminoantipyrine. J. Pharm . Sci ., 50, 393-395.

Ibrahim, S. A; Alaa , S. A. (2007). Spectrophotometric microdetermination of phenylephrine hydrochloride in pure and in pharmaceutical formulation using haemotxylin, J. Molecular Liquids, 130 (1-3) , 84-87.

Kazemipour, M. ; Ansari, M. (2005). Derivative spectrophotometry for simultaneous analysis of chlorpheniramine maleate, phenylephrine $\mathrm{HCl}$ and phenylpropanolamine $\mathrm{HCl}$ in ternary mixtures and pharmaceutical dosage forms. Iranian J. Pharm. Res., 3 , 147-153 .

Kelly, C. ; Auerbach, M. (2006). Ion exchange separation and Colorimetric determination of phenylephrine in pharmaceutical products. J. Pharm. Sci. , 50(6) , 490-493. 
Spectrophotometric Determination............

Knochen, M. ; Giglio, (2004). Flow injection determination of phenylephrine hydrochloride in pharmaceutical dosage forms with on-line solid-phase extraction and spectrophotometric detection . J. , Talanta , 64(5),1226-1232.

Louis , St. (1985). "Drug Facts and Comparisons." , A Division of J.B. Lippinco company, Toronto, 674p.

Matthew ,W. R. ; Browne , H.C. ; Weber , J. B.(1972). Rapid method for the determination of numerous pharmaceutical preparations. J. Ass. off. Anal. Chem. , 55(4), 789-793 ; Anal. Abstr., (1973), 24, 1088 .

Marin, A. ; Barbas , C. , (2004). CE versus HPLC for the dissolution test in pharmaceutical formulation containing acetaminophen, phenylephrine and chlorpheniramine. $J$. Pham. Biomed . Anal. , 35(4), 769-777.

Muszalska , I.; Zajac, M.; Wrobel, G. ; Nogowska, M. (2000). UV/VIS spectrophotometric method for determination of caffeine and phenylephrine hydrochloride in complex pharmaceutical preparation. Validation of method, ActaPol-Pharm. , 57, 247-252.

Neil , H.B. ; Gelenn , A.P. (1971). Analysis of phenylephrine and phenylpropanolamine hydrochloride in combination, J. Pharm. Sci., 60 (8),1229-1231 .

Samir, J. ; Uma, P. (2005). Synthesis and application of novel 4,5,6,7tetrahydrobenzothiazole based azo disperse dye. Arkivoc, 141-149.

Sane, R.T. ; Narkar , V.S. (1980). Colorimetric estimation of phenylephrine hydrochloride, Indian Drugs . 18(1), 23-24; Anal. Abstr. (1981), 41,6E60.

Senyuva, H. ; Ozden, T. (2002). Simultaneous high-performance liquid chromatographyic determination of paracetamol, phenylephrine hydrochloride and chlopheiramine maleate in pharmaceutical dosage forms, J. Chromatogr. Sci., 40 (2) , 97-100.

Szekeres , L. ; Harmon , E. ; Gupta , S. K. (1973). Spectrophotometric determination of phenylephrine hydrochloride, Microchem. J., 18 ,583-588.

Tammilehto, S. ; Farmaseuttinen Aikak, (1975).Determination of ephedrine, metaoxedrine [phenylephrine] and isoprenaline in pharmaceutical preparations as dinitrophenyl derivatives, Farmaseuttinen Aikak, 84(2), 53-59; Anal. Abstr.(1976),_31, 3E33.

Tatsuzawa, M. ; Shimoda, M. (1968). Spectrophotometric determination of phenylephrine hydrochloride in pharmaceutical preparations. Bunseki Kagaku, 17(5), 551-555; Chem. Abstr. (1969), 69,46091h .

Yahia, M. D. ; Laila, N. G. (1976). Colorimetric determination of phenylephrine hydrochloride in pharmaceutical preparation. Analyst. 101 ,717-719.

Yolanda , F.M. ; Luis, L. Z. ; Jose, M.C. (2001). Determination of phenylephrine hydrochloride by flow injection analysis with chemiluminescence detection , $J$. AOAC Int. , 84(1),13-18. 